\title{
Litigating Regionalism in Italy: \\ The Constitutional Court and the Dynamics of the Territorial Constitution
}

\section{Italian Regionalism Before the Constitutional Court}

Whether Italy is a quasi-federal system, or a decentralised unitary state is a matter of scholarly disagreement. ${ }^{1}$ Undoubtedly, the answer to this question depends on the criteria applied when ascribing Italy to either taxonomy. As it lacks a chamber representing regions at the national level, ${ }^{2}$ for instance, U.S.-related approaches to federalism rank Italy among non-federal jurisdictions.

Such uncertainty suggests we reappraise Italian regionalism from an alternative perspective. This article focuses indeed on the dynamics of the Italian constitution, as well as on the actors that allow them to evolve, in order to grasp its most relevant features. Beginning with the dynamics, these revolve around the concept of 'territorial constitution', which points to the geography of federal arrangements, i.e. the governance through constituent units. In federal arrangements, the vertical distribution of powers is complemented by other forces, such as territorial interests, which are allocated within regional boundaries and demarcated on a geographical basis. ${ }^{3}$

The territorial constitution permits us to sidestep the objections that arise under traditional, and formalistic, approaches to federal studies. Not only is it shared by federalising and decentralising processes, but it has also played a pivotal role in those processes not included among mature or emergent federations. ${ }^{4}$ Italy certainly has a

\footnotetext{
${ }^{1}$ On this disagreement see Palermo, Francesco 2007: Italien: Regional- oder Bundesstaat? Jedenfalls asymmetrisch! Auf dem Weg zu asymmetrischem Föderalismus?, in: Palermo/Francesco u.a., Auf dem Weg zu asymmetrischem Föderalismus, Baden Badem, S. 97-108; Breton, Albert/Fraschini, Angela 2016: Is Italy a Federal or even a Quasi-Federal State?, in: POLIS Working Papers n. 234/2016, Alessandria. http://polis.unipmn.it/pubbl/RePEc/uca/ucapdv/polis0234.pdf (08.05.2020).

${ }^{2}$ See eg. Palermo, Francesco 2018: Beyond Second Chambers: Alternative Representation of Territorial Interests and Their Reasons, in: Perspectives on Federalism, Jg. 10, Nr. 2, S. 60, who defines the Italian Senate as a "purely political chamber."

${ }^{3}$ Walker, Neil 2016: The Territorial Constitution and the Future of Scotland, in: McHarg, Aileen et al. (Hrgs.), The Scottish Independence Referendum: Constitutional and Political Implications, Oxford, S. 248; Nicolini, Matteo 2019: Reforming the territorial constitution in Italy: some reflections on durability and change, in: Abels, Gabriele/Battke, Jan (Hrsg.), Regional Governance in the EU: Regions and the Future of Europe, Cheltenham and Northampton, MA, S. 106.

${ }^{4}$ Watts, Ronald L. 2013: Typologies of Federalism, in: Loughlin, John u. a. (Hrgs.), The Routledge Handbook of Regionalism and Federalism; Abingdon, S. 25.
} 
territorial constitution, since the distribution of powers intermingles with interests that are geographically allocated within regional boundaries. Legislative, administrative, and financial responsibilities are constitutionally assigned to regions so that these must meet the needs of their political communities. ${ }^{5}$

This is apparent when we consider the role played by the Italian Constitutional Court (hereinafter: ICC) in favouring the connections between territories and interests by way of constitutional interpretation. ${ }^{6}$ Like its federal counterparts, the ICC has allowed the regional framework to evolve and adapt to several changing (socio-political, economic, and historic) circumstances. Not only has it elucidated the meaning, scope, and application of the distribution of powers, but it has also elaborated judicial techniques and rules of construction in order to accommodate regions' self-rule with the 'strategic role' the constitution assigns to the state. ${ }^{7}$ In the aftermath of the 2001 constitutional reforms, for example, the ICC rendered several rulings with centripetal effects. Examples of this trend are those judgments establishing a peculiar doctrine of subsidiarity, which allows the state to attract legislative powers vested in the regions if this is necessary to address national concerns.

The ICC has thus demarcated the precincts of the territorial constitution. Apart from settling disputes related to regional boundaries, ${ }^{8}$ it has labelled Italy a "regional state". 9 This means, among other things, that secession is incompatible with the constitutional framework. ${ }^{10}$ Although the constitution safeguards their sphere of autonomy, legislative councils are not "sovereign organs"; 11 nor can they claim "regional" sovereignty. ${ }^{12}$ Furthermore, they may enact basic laws (statuti), but not subnational constitutions. ${ }^{13}$

\footnotetext{
${ }^{5}$ See Desideri, Carlo 2015: Regioni politiche e territori. Per una storia del regionalismo italiano, Mailand.

${ }^{6}$ See eg. ICC rulings no. 829/1988 and 51/1991.

${ }^{7}$ See $§ 4$.

${ }^{8}$ Such as in the dispute between the Veneto and the Trentino-Alto Adige regions concerning the boundary on the watershed of the Marmolada Glacier: see ICC ruling no. 743/1988.

${ }^{9}$ Eg. rulings no. 229/1989, 21/1997, and 219/2013.

${ }^{10}$ Ruling no. $118 / 2015$.

${ }^{11}$ See rulings no. 110/1970, 115/1972, 301/2007, 337/2009, 39/2014, 15/2019, 43/2019, and 20/2020.

${ }^{12}$ Ruling no. $365 / 2007$.

${ }^{13}$ Ruling no. 372/2003. See Delledonne, Giacomo/Martinico Giuseppe 2009: Handle with Care! The Regional Charters and Italian Constitutionalism's 'Grey Zone', in European Constitutional Law Review, Jg. 5, Nr. 5, S. 218-236.
} 
This has repercussions, say, on the denomination of councils: the legislative branch at national level is the sole Italian Parliament. ${ }^{14}$ Within this framework, regional legislatures are the representative bodies of the people of the regions, and enjoy the powers endowed to them by the constitutional legal system.

2. Prevention, Adjudication, and Evolution: The Narratives of Italy's Territorial Constitution

The article argues that the ICC's contribution to the dynamics of Italian regionalism is both substantive and procedural. Its role is related to the distribution of powers on regional grounds and to the proceedings whereby the ICC shapes such dynamics.

That the ICC plays such a role is apparent when we consider the steady increase in regional litigation after the 2001 reforms: state-region legislative litigation constitutes more than one-third of the total workload of the ICC. ${ }^{15}$

Judicial review is thus a structural element in Italian regionalism. Like classical federations, Italy experiences a connection between constitutional litigation and variables that have some bearing on its territorial dynamics. Firstly, the distribution of powers between national government and regions is laid out in the 1948 rigid constitution, which binds both levels under the conclusive interpretation of the ICC. ${ }^{16}$ Secondly, this connection refashions the black-letter constitution and judicially construes how powers are actually allotted. ${ }^{17}$ Thirdly, the refashioning depends on how both access to the ICC and constitutional litigation are arranged. ${ }^{18}$ Finally, judicial doctrines and techniques employed by the ICC have generated considerable changes in the territorial constitution. The ICC contributes to shape Italian regionalism along three constitutional lines, i.e. prevention, adjudication, and evolution.

\footnotetext{
${ }^{14}$ Ruling no. $106 / 2002$.

${ }^{15}$ See the ICC's annual report (Giurisprudenza costituzionale dell'anno 2019 dati quantitativi e di analisi) https://www.cortecostituzionale.it/documenti/relazione_cartabia/4_servizio_studi_stat.pdf (08.05.2020).

${ }^{16}$ On constitutional adjudicators as independent and tenured judiciaries see Aroney, Nicholas 2009: The Constitution of a Federal Commonwealth: The Making and Meaning of the Australian Constitution, Cambridge, S. 93.

${ }^{17}$ See eg. rulings no. 106/2002 and 282/2002.

${ }^{18}$ See eg. rulings no. 94/2004, 304/2002, and 274/2003.
} 
Prevention usually refers to mechanisms that ensure intergovernmental collaboration in areas where responsibilities are shared, such as cooperative regionalism. Certainly, the ICC has shaped cooperation among tiers of government. What I argue here is that, in accommodating self-rule and shared rule, ${ }^{19}$ the same distribution of competences attempts to eliminate, i.e. prevent, possible causes for conflicts among levels of government.

The article will therefore outline the regional framework within which the dynamics of the Italian territorial constitution take place; at the same time, these will be considered through the lenses of constitutional litigation.

Take, for example, the relations between regional basic laws and state laws. These are governed by the criterion of competence: as the ICC holds, regional basic laws regulate specific fields of legislation to the exclusion of state ordinary laws. ${ }^{20}$ The Court added fuel to intricacies of the distribution of powers, holding that regional basic laws have to be consistent with state legislation in financial matters. ${ }^{21}$ In a recent judgement, however, it went back in and restored their pristine effectiveness; not only are basic laws assigned matters to the exclusion of state legislation, but they are also hierarchically superior to other regional laws. ${ }^{22}$

Besides avoiding conflicts between state and regions, such rules of construction are the outcomes of judicial interpretation, and, to various degrees, part of constitutional evolution.

Adjudication comes into the picture when prevention is unsuccessful, and conflicts of competencies arise. It is not just a matter of either disentangling the intricacies of the distribution of powers or matching the rapid changes in territorial communities. Evidently, constitutional adjudication is also servient to the evolution and governance of the territorial constitution.

3. Distributing and Interpreting: Prevention and the Dynamics of the Territorial Constitution

\footnotetext{
${ }^{19}$ Elazar, Daniel J 1987: Exploring Federalism, Tuscaloosa, S. 12.

${ }^{20}$ See ICC rulings no. 188/2007, 201/2008, 182/2011, and 188/2011.

${ }^{21}$ Ruling no. 35/2014.

${ }^{22}$ ICC rulings no. 48/1983, 993/1988, 118/2006, 201/2008, and 81/2015.
} 
The territorial constitution was created by giving a strong voice to the identities of the different areas and territories of the Italian Peninsula. ${ }^{23}$

The constitution establishes twenty regions (Art. 131), whose territorial demarcation, as the ICC maintains, cannot be unilaterally altered by national Parliament: the regional population must consent to such an alteration through a referendum. ${ }^{24}$

Five of the twenty regions are labelled "special" regions, as their powers are listed in their basic laws approved with a constitutional state law (Article 116.1). ${ }^{25}$ They correspond to ethnic and geographical reasons: they possess differentiated responsibilities because they have to meet the ethnic, linguistic, and legal needs of their respective communities. ${ }^{26}$ For instance, the ICC acknowledged that Trentino-Alto Adige/Südtirol can pass legislation in private law in order to regulate the Bauernhof, i.e. the typical Austro-Tyrolean farmyard. ${ }^{27}$

Friuli-Venezia Giulia, Aosta Valley/Vallée d'Aoste, and Trentino-Alto Adige/Südtirol regions are border regions with the presence of linguistic minorities, whose protection is part of the fundamental features of the Italian constitution (Art. 6). Consequently, the ICC ruled that constitutional and state legislation outline the general framework, whereas regional legislative action must be localised within the regional borders. ${ }^{28}$

This geographical accommodation is well illustrated by the implementation of territorial and power-sharing mechanisms in the border regions where several communities coexist. The basic law for the Trentino-Alto Adige region (Art. 56), for example, allows linguistic groups represented within Regional and Provincial legislatures to challenge a bill that affects their mutual relations before the ICC. This ex ante judicial scrutiny is servient to

\footnotetext{
${ }^{23}$ See Nicolini 2019; Desideri, Carlo 2014: A Short History of Regionalism in Italy Since the Republican Constitution. Italian Regionalism and Its Evolution, in: Mangiameli, Stelio (Hrgs.), Italian Regionalism, S. 35 .

${ }^{24}$ Art. 132 Const. See rulings no. 334/2004, 66/2007. New regions must have a minimum of one million inhabitants (ruling no. 278/2011).

25 Trentino-Alto Adige/Südtirol, Friuli-Venezia Giulia, Aosta Valley, Sicily and Sardinia. Within the Trentino-Alto Adige/Südtirol region the provinces of Trento and Bolzano/Bozen have legislative powers (Art. 116.2, Const.), but legislative inter-delegation of powers is prohibited (ruling no. 132/2006).

${ }^{26}$ See Palermo, Francesco 2015: Owned or Shared? Territorial Autonomy in the Minority Discourse, in: Malloy, Tove H./F. Palermo, Francesco (Hrgs.), Minority Accommodation through Territorial and NonTerritorial Autonomy, Oxford, SS. 13-32.

27 Article 8.8 basic law for the Trentino-Alto Adige/Südtirol region; ICC rulings no. 4/1956, 35/1972, 505/1988, 173/2010, and 193/2017.

${ }^{28}$ Rulings no. 32/60, 1/1961, 46/1965, 312/1983, 159/2009, and 170/2010. On the constitutionality of ethnic-oriented census in the Alto-Adige/Südtirol region see rulings no. 289/1987 and 768/1988.
} 
minority protection, prevention of conflicts, and the interpretation of the territorial constitution. ${ }^{29}$

The remaining fifteen "ordinary" regions have their power listed in the national constitution. They can petition for the conferral of "additional special forms and conditions of autonomy" upon their initiative (Article 116.3). Such a procedure, though, does not allow them to become special regions (ruling no. 118/2015).

Regional powers have undergone profound changes in the last few decades. Constitutional (amendment) acts no. 1/1999 and 2/2001 broadened regional constitutional autonomy. Constitutional act no. 2/2001, in particular, granted special regions the capability to determine their form of government and electoral system by adopting an act by absolute majority of the members of the regional legislature. The ICC considers these acts expressions of constitutional autonomy (ruling no. 370/2006).

Constitutional (amendment) act no. 3/2001 modified the distribution of powers. Whereas former Article 117 allowed regions to make laws providing that there was a constitutional foundation of their legislative powers, these now encounter only those limitations deriving from the existence of a subject matter reserved to state legislative powers (ruling no. $282 / 2002)$.

Despite this, however, the distribution of legislative powers is particularly convoluted. Regions are vested with residuary powers (Article 117.4), and the State has exclusive jurisdiction in the subject matters listed in Article 117.2 - and this partially overlaps with several regional specified heads of competence. Article 117.3 lists the subject matters covered by concurring legislation: legislative powers are vested in the Regions, except for the determination of the fundamental principles, which are laid down in State legislation. As the ICC has clarified, if regional laws infringe such fundamental principles, they are inconsistent with the constitution and therefore must be struck down. $^{30}$

4. Prevention Through Litigation: Rearranging Constitutional Arrangements

\footnotetext{
${ }^{29}$ Rulings no. $216 / 1995,356 / 1988$, and 190/2019.

${ }^{30}$ Rulings no. 161/2012, 3/2013, and 14/2018.
} 
Allocated on a regional basis, territorial interests may encroach upon other forces and interests, which may be supra-regional or advocate for their uniform implementation. There is also the EU integration process: regions take part in both the elaboration and implementation of EU legislation in subject matters falling within their jurisdictions; Articles 117.5 and 120.2 Const. vest the State with substitutive powers in case regions do not fulfil EU obligations (rulings no. 227/2004 and 152/2015).

Therefore, it may occur that the distribution of powers matches neither supra-regional interests nor the need for their uniform implementation. As it is impossible to ignore the powers constitutionally assigned to regions, two possibilities have arisen. On the one hand, the ICC has elaborated judicial techniques in order to accommodate regions' selfrule with legal and economic unity within the Republic. On the other hand, and through litigation, it has developed alternative paths of prevention leading to a substantial refashioning of the constitutional arrangements.

We shall see in due course their effects on Italian regionalism; in this paragraph I will focus on their judicial refashioning.

Take, for example, EU powers, which frequently overlap with regional ones. Since EU law is supreme over national law, this has caused the 'Europeanisation' of regional competences. ${ }^{31}$ According to the ICC, EU legislation does not have to respect the distribution of powers set forth in the Constitution. The EU is free to allocate its powers between state and regions according to the criteria enunciated in the EU Treaties. ${ }^{32}$ This is due to Article 117.1 of the Constitution, which binds state and regional legislation to the respect of EU constraints and calls for compliance with EU law. In cases of conflict between regional law and EU law, the latter prevails. ${ }^{33}$

EU law intertwines with supra-regional interests in the field of intergovernmental financial relations. The 2001 constitutional reform also modified the distribution of finance setting the framework for revenue and expenditure powers, fiscal arrangements,

\footnotetext{
${ }^{31}$ See Carter, Caitriona/Pasquier, Romain 2010: The Europeanisation of Regions as 'Spaces for Politics': A Research Agenda, in: Regional and Federal Studies, Jg. 20, Nr. 3: S. 295-314. On Italy see Nicolini, Matteo 2009: Partecipazione regionale e «norme di procedura». Profili di diritto costituzionale italiano ed europeo, Neapel.

32 Rulings no. 399/1987, 458/1995, 126/1996, and 286/2005.

33 Rulings no. n. 384/1994, 94/1995, 406/2005, 126/2006, 102/2008, n. 28/2010, 18/2012, 66/2013, $171 / 2013,269 / 2014,38 / 2015$, and 161/2019.
} 
financial responsibility, and equalisation (Article 119). ${ }^{34}$ This, though, did not prevent the ICC from limiting regional and local revenue and expenditure powers in order to fight against the economic crisis. Holding down the raise of the public debt meant adopting severe cuts on the amount of the grants transferred to regions, provinces and municipalities. ${ }^{35}$

Furthermore, constitutional (amendment) act no. 1/2012 reformed the budgetary rules introducing the principle of balance between revenue and expenditure (article 81 Const.). It then amended Article 119 Const. by stating that EU financial constraints can limit regional and local financial powers; ${ }^{36}$ this entails a uniform management of financial matters (ruling no. 61/2018), also in the light of the supremacy of the EU. ${ }^{37}$

The judicial refashioning of the constitutional distribution of powers is also servient to the protection of the legal and economic unity of the Republic, as well as to the uniform implementation of interests allocated at the national level. The 2001 reform has created several intricacies in the distribution of competences making adjustments in terms of constitutional litigation necessary. The formal distribution of powers, for example, assigns regions concurrent legislative powers in areas such as "national production, transportation and distribution of energy" (Article 117.3 Const.), and residual powers (Article 117.4 Const.), among other things, in ambits such as traffic and circulation, which are traditionally regulated by state law.

The new distribution of competences remained largely on paper and its practical design has been determined by the ICC. Several rulings developed a centralistic doctrine and established a peculiar doctrine of subsidiarity (set in Article 118, I of the Constitution). In order to comply with the national concern, the state can enact laws in fields the constitution assigns to regions. ${ }^{38}$

Finally, the 2001 reform, which only addressed ordinary regions, did not have a direct impact on the competences of special regions, whose powers still derive from their basic laws. Moreover, Article 10 of constitutional act no. 3/2001 establishes that, as long as the

\footnotetext{
${ }^{34}$ On such framework see rulings no. 370/2003, 296/2003, 37/2004, 451/2007, 288/2012, and 199/2016.

${ }^{35}$ On the constraints set to expenditure powers see rulings no. 289/2008, 139/2009, 237/2009.

${ }^{36}$ See ruling no. 184/2016. See Delledonne, Giacomo 2018: La Constitution budgétaire, composante de la Constitution économique dans la longue transition de l'État régional italien, in: Politeia, Nr. 34, S. 289-306.

${ }^{37}$ See rulings no. 207/2010, 182/2011, 236/2013, 36/2014, 19/2015, 218/2015, 65/2016.

${ }^{38}$ See rulings no. 303/2003, 6/2004, 383/2005, 278/2010, 232/2011, 163/2011, 7/2016, 61/2018, and $161 / 2019$.
} 
autonomous regions do not change their basic laws, the broader forms of legislative autonomy set out in Title V Const. for ordinary regions applies to them as well. In sum, the legislative powers of special regions can be considered as the outcome of the intersection of (often overlapping and contradicting) catalogues contained both in the national constitution and in their own basic laws. ${ }^{39}$

This provision also allowed the ICC to refashion the constitutional litigation between the state and the special regions. Under special basic laws, the national government may challenge the validity of regional laws before the ICC prior to their enactment, whereas, as regards ordinary regions, this type of litigation is now ex post in character. As the latter constitutes a broader form of autonomy, Article 10 of constitutional act no. 3/2001 makes it applicable also to special regions - as the ICC has repeatedly held. ${ }^{40}$

\section{How Adjudication Works. Judicial Proceedings as Patterns of Centralisation}

Such a judicial refashioning mirrors several forces percolating through the territorial constitution. Not only is this the result of their encroaching upon the territorial constitution, but it also reflects how constitutional adjudication is per se able to shape regional and territorial dynamics.

When referring to "constitutional adjudication", we consider two types of proceedings. On the one hand, there is the judicial review of legislation, through which the ICC strikes down unconstitutional laws on the grounds that they are enacted ultra vires. This review is incidental, when judges are allowed to question the constitutionality of a law before the ICC (Article 134.1 Const.). The access may also be direct: the national government may refer a regional law - vice versa, a regional executive may bring a state law - to the ICC for allegedly being inconsistent with the constitutional distribution of powers (Article 127 Const.). In both cases, if the ICC determines that a national or regional law disregards the distribution of powers, this will be declared unconstitutional to the extent of the inconsistency and for that reason invalid.

\footnotetext{
39 See Ruggiu, Ilenia 2011: Le "nuove” materie spettanti alle Regioni speciali in virtù dell'art. 10, legge costituzionale 3/2001, in: Le Regioni, Nr. 5, S. 775-820.

${ }^{40}$ See rulings no. 65/2002, 377/2002, 408/2002, 533/2002, and 255/2014.
} 
On the other hand, the ICC guarantees the supremacy of the constitution through arbitration processes, settling cases and controversies between national and regional units at the sub-legislative level (Article 134.3 Const.).

Substantive and judicial entanglements are apparent when considering how the ICC understands the dialectics between unity and regional autonomy. According to Art. 5 Const., the Republic recognises and promotes local, i.e. territorial, autonomies; at the same time, it acts as the political guarantor of its own "unity" and "indivisibility".

Such unitarist commitment is also shared by legal guarantor of the constitution, i.e. the ICC. The consequences are twofold. Firstly, these centralising trends affect how the ICC has been construing, interpreting, and adapting the patterns of constitutional adjudication. Secondly, they refer to how the state coordinates the polyarchy of territorial entities, which are part of the Italian territorial constitution.

Beginning with the patterns of adjudication, several centralising trends characterise how the ICC judicially construes its role within constitutional litigation. As territorial pluralism must be coordinated both politically and judicially, the ICC draws an equation between national Parliament and itself. Not only does the constitution establish a sole political guarantor (rulings no. 106/2002, 274/2003, and 303/2003), but it also vests constitutional litigation only in the ICC. Unlike the German Basic Law (Article 93.4), Italy's constitution sets a polyarchy of regional units but not a polyarchy of constitutional adjudicators. No wonder, therefore, that the ICC stroke down several provisions of the basic law for the Sicily region entrusting a regional court, the High Court for Sicily, with state-region constitutional disputes and the impeachment of the regional president. ${ }^{41}$ There are other patterns of litigation which contribute to boosting these centralising trends at the expenses of politico-territorial pluralism. The first pattern relates to how legislation is brought before the ICC. As far as regional legislation is concerned, we have already noticed that the 2001 constitutional reform altered this type of judicial review. Under the 1948 constitution, regional laws were certified prior to their entry into force; now, the scrutiny takes place after they have been enacted. Like Article 143 of the current Belgian constitution, former Article 127 Const. also allowed Parliament to settle conflicts of interest that could arise between the state and regions. The scrutiny, which was never

\footnotetext{
${ }^{41}$ Arts. 25 to 27 Basic Law for the Sicily region. See rulings no. 38/1957, 6/1970, and 161/2001.
} 
applied, had a pre-enactment character and was political in nature: Parliament, not the ICC, settled the conflicts. ${ }^{42}$

This changed when constitutional (amendment) act no. 3/2001 altered Article 127. Now both the national government and the regional executives can challenge the constitutional validity of laws within 60 days from their publication in the official gazette.

From this, however, it does not follow that the state and regions are now put on an equal footing before the ICC. There is still an asymmetry between their respective standings. The national government may indeed file a case when regional laws exceed 'regional competence in the broadest sense of the word: any breach of the Constitution could justify [a] challenge'. ${ }^{43}$ By contrast, regions may challenge state laws - as well as the laws of other regions ${ }^{44}$, , provided that these interfere with their constitutionally assigned sphere of competence.

Nor did the 1999-2001 reforms put an end to the ex ante scrutiny. Constitutional (amendment) acts no. 1/1999 and 2/2001 introduced an ex ante judicial certification of regional basic laws, which national government can challenge before the ICC within 30 days from their notification in the official gazette. The ICC acknowledged that this $e x$ ante judicial certification is a new type of certification (ruling no. 304/2002), which has widened the scope for the ICC judicial intervention in the organisation and functioning of both types of regions. ${ }^{45}$ This certification is indeed aimed at preventing conflicts between the fundamental principles of the constitution and subnational units' constitutional systems. Article 123 requires regional basic laws to be "in compliance with the Constitution". This is a very broad and vague notion, which ultimately leaves both regional constitutional autonomy and its scope in the hands of the ICC.

\footnotetext{
${ }^{42}$ See Paladin, Livio 2000: Diritto regionale, Padua, 414-418.

${ }^{43}$ D'Amico, Marilisa 2019: The Constitutional Court, in A Helen and D Haljan (Hrgs.), Constitutional Law in Italy (Alphen aan den Rijn, S. 212; Ronchetti 2014, S. 230. See also ICC ruling no. 274/2003, 4/2004, and 50/2005.

44 This type of litigation has $t$ resulted in a handful number of judgments: see ICC rulings no. 533/2002, $296 / 2009$, and 251/2015.

${ }^{45}$ See ICC rulings no. 304/ 2002, 196/2003, 2/2004, 372/2004, 378/2004, 379/2004, 12/2006, and 63/2012. See Cardone, Andrea 2007: La 'terza via' al giudizio di legittimità costituzionale. Contributo allo studio del controllo di costituzionalità degli statuti regionali, Mailand; Delledonne, Giacomo u.a. 2020: Italy, in: Popelier/Patricia u.a. (Hrgs.), Routledge Handbook of Subnational Constitutions and Constitutionalism, Abingdon.
} 
A few regions tried to seize the occasion of the elaboration of their new basic laws in order to strengthen their effective autonomy. The Emilia-Romagna, Tuscany, and Umbria regions included some provisions on their goals that mirrored some fundamental rights beyond the national catalogue (such as the "right to knowledge", the "rights of people with disabilities", the "recognition" of forms of family life beyond marriage, and so on). The ICC found that these provisions are declaratory in nature, and therefore not binding; hence, they cannot contradict the constitution inasmuch as they lack legal effects (rulings no. 2,378 , and $379 / 2004)$.

\section{Bargaining Competences: The Special Regions}

The unitarist commitment shared by the ICC also triggered further consequences, in relation to which constitutional adjudication becomes servient to the coordination of state-region relations. To a broader extent, judicial coordination of territorial pluralism accounts for the third narrative of Italian regionalism, i.e. that of evolution.

These consequences are usually conceived of as the outcome of both prevention and resolution. Doctrines, techniques, and accommodation which the ICC employs in avoiding, preventing and resolving conflicts have generated considerable changes in the territorial dynamics of the constitution. Firstly, judicial conflicts regard the scope of powers constitutionally attributed to a specific level of government. Further, imbrications between national and subnational jurisdictions, as well as overlaps between their powers, require mechanisms of collaboration and consultation between the different levels of government.

I understand that one of these types of evolution is triggered by the bargaining of regional competences, i.e. one of the main legacies of the pre-2001 forms of judicial review of legislation. Taking place during the ex ante scrutiny on regional laws, the negotiation tried to limit litigation before the ICC - or, in the case of conflicts of interests, before Parliament. This transactional activity, however, entrusted the state with a strategic role in areas of state-region overlapping jurisdictions. Under no circumstances was the transaction merely aimed at drawing more precise boundaries between the scope of their respective jurisdictions. By contrast, it reflected the imbalance of powers between state 
interests requiring a uniform implementation and regional interests allocated at the subnational level of government.

As already said, state-region litigation now takes place after the enactment of regional laws. This has made the bargaining of competences part of the judicial strategies of both state and regions. The ICC roll is now populated with "the lapsing of causes of action, cessation of matter, or the extinction of the proceeding"; while "awaiting the [ICC]'s rulings," regions usually change or repeal the provision which has been challenged, therefore "removing the need to appeal."

Such a strategic negotiation can be traced back to the origins of Italian regionalism. As is known, ordinary regions were created in $1970,{ }^{47}$ whereas in the previous decades (1940s1960s) only special regions were effectively established. Special basic laws assigned regions differentiated statuses and powers, as is typical of federal asymmetric systems. This prompted the establishment of bilateral relations, which still characterise, among the other things, the implementation of their basic laws through legislative decrees. The basic laws of special regions provide for the creation of joint committees (one committee for each region) composed of an equal number of members appointed by central and regional governments which draft the text of the legislative decrees to be subsequently adopted by the national government. ${ }^{48}$

Bilateral cooperative mechanisms have also shaped their financial relations with the state. Special basic laws can be amended by either an act at constitutional level approved by Parliament or by an act at primary-legislative level. ${ }^{49}$ The latter is possible if there is an agreement between the state and the segion concerned. As the ICC holds, the act of Parliament based on a state-segion agreement counts as a constitutional amendment. ${ }^{50}$

\footnotetext{
${ }^{46}$ Ronchetti 2014, S. 383.

${ }^{47}$ See Desideri 2014.

${ }^{48}$ Article 43 basic law for Sicily; Article 56 basic law for Sardinia, Article 107 basic law for Trentino-Alto Adige/Südtirol; Article 65 basic law for Friuli-Venezia Giulia; Article 48bis basic law for Valle d'Aosta/Vallée d'Aoste. See ICC ruling no. 316/2004.

${ }^{49}$ Article 54, IV, basic law for Sardinia; Article 50, V, basic law for Valle d'Aosta/Vallée d'Aoste; Article 63, V, basic law for Friuli Venezia-Giulia; Article 104, I, basic law for Trentino Alto-Adige/Südtirol.

${ }^{50}$ Rulings no. 99/2014, 46/2015, 77/2015, 82/2015, and 28/2016.
} 
Finally, the EU integration process and the financial crisis also set constraints on such bilateral negotiations when it comes to implementing the fiscal powers of the special regions. ${ }^{51}$

7. Patterns of Evolution. Decentralisation, Cooperation and ... Back Again to Centralisation

Several patterns of evolution may be inferred from how state and regions bargained their respective spheres of competences under the pre-2001 constitutional arrangements. Together with bilateralism, the practice of legislative, as well as financial, negotiation among levels of governments are mechanisms that fall under the umbrella of what, in modern parlance, we term as cooperative federalism. The Italian constitution has always been silent as regards the principle of federal comity. A reference to it was introduced only in 2001 in order to set the benchmark for the exercise of state substitutive powers vis-à-vis regional and local inactivity (Article 120.2). Apart from this exception, the principle of federal comity is an outcome of judicial creativity, ${ }^{52}$ which is traceable back to $1950-1960$ state-special regions bilateralism. ${ }^{53}$

From the 1970s onwards, the ICC has made a wide use of cooperative regionalism in order to allow regions to have a say in law-making processes at the state level if competences are so imbricated that it is possible to disentangle them. ${ }^{54}$ The ICC has applied it in order to counterbalance the centripetal effects the doctrine of subsidiarity has on regional competences, ${ }^{55}$ and to have regions involved in the national law-making processes in areas of common concern, such the organisation of the public administration and financial matters. ${ }^{56}$ In addition, it has stimulated the increase in intergovernmental relations and in consultations as a form of participation; ${ }^{57}$ at the same time, it has put

\footnotetext{
${ }^{51}$ See eg. ICC rulings no. 376/2003, 414/2004, and 399/2006.

${ }^{52}$ Bartole, Sergio 1985: Art. 117, in: Branca, Giuseppe (Hrgs.), Commentario della Costituzione, Art. 114120, Rom u. Bolonia, S. 217-218; See Poggi, Annamaria 2017: Corte costituzionale e principio di 'lealtà' nella collaborazione tra Stato e Regioni per l'esercizio delle funzioni, in: Federalismi.it, Nr. 19, S. 1.

${ }^{53}$ Eg rulings no. 21/1956 and 49/1958. See Poggi 2017, S.4-6.

${ }^{54}$ See Bartole 1985; Poggi 2017, S. 6-15. Rulings no. 175/1976, 219/1984, 187/1985, 31/2006, 251/2016.

${ }^{55}$ Rulings no. 165/2001, 39/2012, and 179/2012. See also rulings no. 437/2001 and 278/2010.

${ }^{56}$ Rulings no. 88/2014.

${ }^{57}$ Rulings no. $129 / 2016$ and 211/2016.
} 
emphasis on the need for multilateral cooperation throughout shared bodies and joint committees, which determine common actions and shared policies. This is the case of the Standing Conference for the Relations between the State and Regions (Conferenza permanente per i rapporti tra lo Stato e le Regioni), a permanent body composed of both the President of the Council of Ministers and the Presidents of regional executives, whose purpose is, in the ICC's reasoning, to accommodate regions' self-rule with state interests when competences are inextricably intertwined. ${ }^{58}$

Yet, cooperative regionalism is judicially constructed so as to reflect how the ICC conceives of its role of legal guarantor of the territorial constitution. The dialectic between territorial pluralism and the need for a uniform implementation of those supra-regional interests allocated at the national level is still evident in the most recent judgements of the Court. ${ }^{59}$

With this in mind, I am not denying the role played by the ICC in fostering regional participation at the national level, as well as in broadening subnational legislative intervention in areas of regional exclusive competence. ${ }^{60}$ When trying to accommodate the manifold "intricacies" in areas of overlapping jurisdictions, ${ }^{61}$ the ICC has traditionally placed more emphasis on its role of guarantor of legal and economic unity than on regional self-rule.

The outcomes of this centripetal attitude are manifold. They are apparent, for example, in how the ICC judicially construed regional competences at the onset of Italian regionalism. The Court cut out the supra-regional interests within regional competences, and subsequently allocated those interests at the state level alongside the quota of legislative action essential for their uniform regulation.

The ICC had already experimented with this technique in the 1950s, when there were only the special regions. ${ }^{62}$ This technique, which aimed to carve out both national, and

\footnotetext{
${ }^{58}$ Rulings no. 116/1994 and 31/2006. See Carpani, Guido, 2006: La Conferenza Stato-regioni. Competenze e modalità di funzionamento dall'istituzione ad oggi, Bolonia.

${ }^{59}$ See eg rulings no. 61/2018 and 74/2018.

${ }^{60}$ The ICC has indeed broadened the scope of regions' residuary powers in several ambits, such as 'shop opening hours' (ruling no. 247/2010), 'fairs and local marketplaces' (no. 1/2004), 'tourism' (no. 90/2006), and 'agriculture' (no. 12/2004).

${ }^{61}$ As the ICC literally termed then: see ruling no. 21/2016.

${ }^{62}$ Rulings no. 7/1956, 28/1958, 50/1958, 58/1958, and 56/1964. See Crisafulli/Vezio 1963: Le regioni davanti alla Corte costituzionale, in: Rivista trimestrale di diritto pubblico, S. 537.
} 
legislative, interests from regional powers, was widely perused as regards ordinary regions as well. ${ }^{63}$ This generated a strict coordination of the different regions in order to secure the superiority of state interests percolating through the constitution. ${ }^{64}$

The aftermath of the 2001 constitutional reform, finally, has experienced several judicial centralising trends without making the necessary constitutional amendments. Where competences intertwine, for instance, the ICC has allowed state competences to prevail over the regional ones in order to address the national concern. ${ }^{65}$ Furthermore, state competences identify "purposes" rather than "objects" of state intervention; therefore, they "cross-cut" regional competences allowing the state to absorb legislative powers constitutionally vested in the regions. ${ }^{66}$

It should be argued, however, that such centripetal dynamics also characterise classical federations. The need for ensuring legal, social, and economic unity unavoidably has some bearing on the subnational self-rule, as the advent of what we may term as 'social federalism' demonstrates. Take, for example, Germany. Owing to the konkurrierende Gesetzgebung laid down in Article 72 GG - which, needless to say, is overseen by the Federal Constitutional Court -, the Federation may absorb Länder's powers in order to ensure minimum standards of income, health, education and welfare to all citizens. ${ }^{67}$

It is not just a matter of applying formal labels or taxonomies to federalising processes. In federal studies, the application of a politico-legal paradigm, such as the 'dynamics' of the territorial constitution, discloses a less formalistic approach when comparing and contrasting different federal frameworks. The focus therefore shifts from the black-letter constitution to how constitutional adjudicators rearrange territorial interests under federal arrangements. In so doing, adjudicators settle conflicts and make the arrangements evolve, thus breathing life into the territorial constitution through interpretation.

\footnotetext{
63 See rulings no. 138/1971, 191/1976, 118/1981, 340/1983, 188/1984, and 18 del 1997. See Falcon, Giandomenico 1981: Prescrizioni costituzionali e indirizzo legislativo nella definizione delle materie regionali, in: Le Regioni, S. 1369;

${ }^{64}$ See Mangiameli/Stelio 1997: L'indirizzo e il coordinamento: una funzione legislativa costituzionalizzata dalla Corte, in: Giurisprudenza Costituzionale, S. 1131.

${ }^{65}$ See ruling no. 282/2002, 370/2003; 213/2006, 196/2004, 407/2002, and 114/2017.

${ }^{66}$ Ronchetti 2014: 394. See ruling no. 370/2003; 405/2007.

${ }^{67}$ See Nicolini, Matteo 2018: The Principles of Separation and Correspondence, the Comparative Method, in: Palermo, Francesco/Valdesalici, Alice (Hrgs.), Comparing Fiscal Federalism, Leiden, S. 89.
} 
As this process of judicial interpretation crosses the traditional federal taxonomies, it ultimately has the merit of providing us with the answer to the question we formulated at the very beginning of the article. Italy may be numbered among the federalising processes not on grounds of taxonomies, but because of its judicially overseen territorial dynamics. And these dynamics, as Germany confirms, are also shared by one of the most classical federalising processes. 